\title{
A case report of sinus hypoplasia
}

\author{
Bir sinüs hipoplazisi olgu sunumu
}

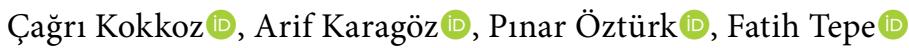 \\ Department of Emergency Medicine, İzmir Çiğli Regional Education Hospital, İzmir, Turkey
}

\begin{abstract}
Transverse sinus (TS) hypoplasia has serious potential effects on cerebral hemodynamics. Right sinus hypoplasia is less common. In this article, we present a rare case of right transverse and sigmoid sinus hypoplasia with headache complaint. A 37-year-old male patient was admitted to the emergency department because of headache and anxiety complaints continuing for the last two days. Neurological examination including fundoscopy was normal. Cranial and diffusion magnetic resonance (MR) imagining, and MR venography were planned to exclude venous sinus thrombosis. According to MR venography, right TS, right sigmoid sinus and jugular bulb were reported as hypoplasic. Patients who apply to the emergency department with headache, anxiety, and nervousness should be considered for transverse and sigmoid sinus hypoplasia.
\end{abstract}

Keywords: Headache; hypoplasia; migraine; sinüs.

öz

Transvers sinüs (TS) hipoplazisi serebral hemodinamikler üzerinde ciddi olası etkilere sahiptir. Sağ sinüs hipoplazisi daha az görülür. Bu yazıda, baş ağrısı yakınması olan nadir bir sağ transvers ve sigmoid sinüs hipoplazisi olgusu sunuldu. Otuz yedi yaşında bir erkek hasta son iki gündür devam eden baş ağrısı ve anksiyete yakınmaları nedeniyle acil servise kabul edildi. Fundoskopi dahil nörolojik muayene normaldi. Venöz sinüs trombozunu dışlamak için kraniyal ve difüzyon manyetik rezonans (MR) görüntüleme ve MR venografi planlandı. MR venografiye göre sağ TS, sağ sigmoid sinüs ve juguler bulb hipoplazik olarak bildirildi. Acil servise baş ağrısı, anksiyete ve asabilik ile başvuran hastalarda transvers ve sigmoid sinüs hipoplazisi dikkate alınmalıdır. Anahtar sözcükler: Baş ağrısı; hipoplazi; migren; sinüs.

The anatomical asymmetry of transverse sinuses (TSes) is common. Unilateral hypoplasia or aplasia of TSes is seen between $20 \%$ and $39 \%$ of cases. $^{[1,2]}$ According to the literature, TS hypoplasia cannot be regarded as a normal variant. Transverse sinus hypoplasia has serious potential effects on cerebral hemodynamics. ${ }^{[3-6]}$ Transverse sinus hypoplasia and aplasia are related to intracranial hypertension without papilledema and they are risk factors for chronic migraine. ${ }^{[7]}$ Right sinus hypoplasia is rarer than left sinus hypoplasia. ${ }^{[8]}$ In this article, we present a rare case of right transverse and sigmoid sinus hypoplasia with headache complaint.

\section{CASE REPORT}

A 37-year-old male patient was admitted to the emergency department because of headache and anxiety complaints continuing for the last two days. In his history, he mentioned about a recurrent headache for a long time. The patient was treated for sinusitis and migraine in his previous emergency department applications. His vital findings were normal with no fever. Neurological examination including fundoscopy was normal. Patient's headache was continuing despite pain medication. Therefore, a computed tomography (CT) of the patient was obtained. No pathological findings were found by $\mathrm{CT}$. 


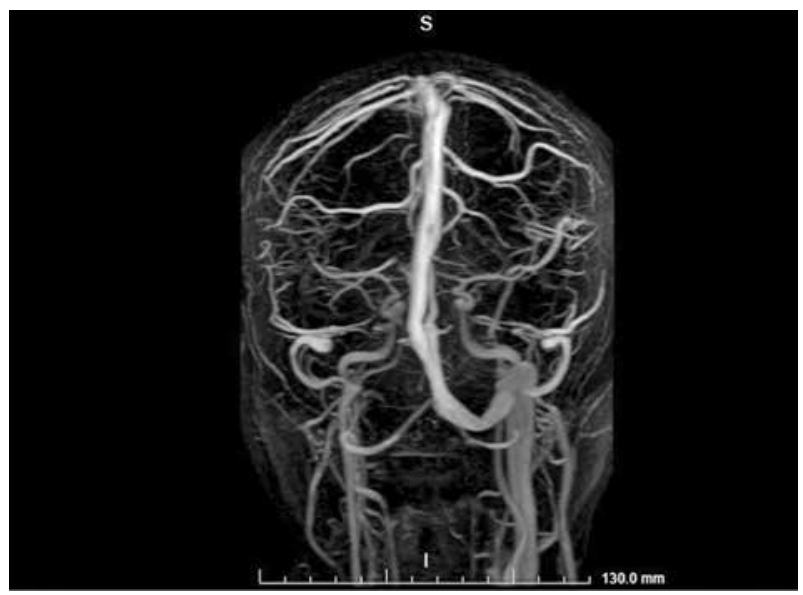

Figure 1. Magnetic resonance venography image showing hypoplasia of right transverse sinus, sigmoid sinus, and jugular bulb.

Cranial and diffusion magnetic resonance imaging (MRI), and MR venography were planned to exclude venous sinus thrombosis. According to MR venography, right TS, right sigmoid sinus and jugular bulb were reported as hypoplasic (Figure 1). A written informed consent was obtained from the patient.

\section{DISCUSSION}

Right TS, right sigmoid sinus, and jugular bulb hypoplasia were detected by MR venography in our patient whose headache did not respond to symptomatic treatment. Similarly, Alper et al. ${ }^{[8]}$ performed MR venography to investigate the presence of aplasia and hypoplasia of TSes in 105 patients. They have found left sinus aplasia in $20 \%$, left sinus hypoplasia in 39\%, right sinus hypoplasia in $6 \%$, right sinus aplasia in $4 \%$, and symmetric sinuses in 3\% of their patients.

Furthermore, Fofi et al. ${ }^{[1]}$ investigated TS morphology with MR venography in 83 patients with chronic migraine and found asymmetry between TSes in 50.6\% of patients. Of the patients, $24.1 \%$ had severe asymmetry between sinuses and $9.6 \%$ had aplasia. Nervous diseases, hypertension, migraine, and anxiety have been reported more often in patients with TS aplasia and hypoplasia.

In a study by Surendrababu et al., ${ }^{[9]}$ MR angiography results of 100 patients were obtained. Accordingly, 13 patients had right TS hypoplasia,
35 patients had left TS hypoplasia, six patients had right sigmoid sinus hypoplasia, and nine patients had left sigmoid sinus hypoplasia.

Finally, Bono et al. ${ }^{[10]}$ compared cerebrospinal fluid pressure of 48 patients with bilateral TS stenosis who suffered headache and 50 patients with normal TSes. In the mentioned study, 48 headache sufferers were reported to have increased intracranial pressure.

In this case report, we presented a patient with right-sided transverse and sigmoid sinus hypoplasia. According to the literature, right TS hypoplasia with right sigmoid sinus hypoplasia is a rare condition. Thus, patients who apply to the emergency department with headache, anxiety, and nervousness should be considered for transverse and sigmoid sinus hypoplasia.

\section{Declaration of conflicting interests}

The authors declared no conflicts of interest with respect to the authorship and/or publication of this article.

\section{Funding}

The authors received no financial support for the research and/or authorship of this article.

\section{REFERENCES}

1. Fofi L, Giugni E, Vadalà R, Vanacore N, Aurilia C, Egeo $G$, et al. Cerebral transverse sinus morphology as detected by MR venography in patients with chronic migraine. Headache 2012;52:1254-61.

2. Frydrychowski AF, Winklewski PJ, Guminski W. Influence of acute jugular vein compression on the cerebral blood flow velocity, pial artery pulsation and width of subarachnoid space in humans. PLoS One 2012;7:e48245.

3. Lin CJ, Chang FC, Tsai FY, Guo WY, Hung SC, Chen DY, et al. Stenotic transverse sinus predisposes to poststenting hyperperfusion syndrome as evidenced by quantitative analysis of peritherapeutic cerebral circulation time. AJNR Am J Neuroradiol 2014;35:1132-6.

4. Yu W, Rives J, Welch B, White J, Stehel E, Samson D. Hypoplasia or occlusion of the ipsilateral cranial venous drainage is associated with early fatal edema of middle cerebral artery infarction. Stroke 2009;40:3736-9.

5. Wilson MH, Davagnanam I, Holland G, Dattani RS, Tamm A, Hirani SP, et al. Cerebral venous system and anatomical predisposition to high-altitude headache. Ann Neurol 2013;73:381-9.

6. Liu $\mathrm{M}, \mathrm{Xu} \mathrm{H}$, Wang $\mathrm{Y}$, Zhong $\mathrm{Y}$, Xia S, Utriainen $\mathrm{D}$, et al. Patterns of chronic venous insufficiency in the dural sinuses and extracranial draining veins and 
their relationship with white matter hyperintensities for patients with Parkinson's disease. J Vasc Surg 2015;61:1511-20.e1.

7. De Simone R, Ranieri A, Cardillo G, Bonavita $\mathrm{V}$. High prevalence of bilateral transverse sinus stenosis-associated IIHWOP in unresponsive chronic headache sufferers: pathogenetic implications in primary headache progression. Cephalalgia 2011;31:763-5.

8. Alper F, Kantarci M, Dane S, Gumustekin K, Onbas $\mathrm{O}$, Durur I. Importance of anatomical asymmetries of transverse sinuses: an MR venographic study. Cerebrovasc Dis 2004;18:236-9.

9. Surendrababu NR, Subathira, Livingstone RS. Variations in the cerebral venous anatomy and pitfalls in the diagnosis of cerebral venous sinus thrombosis: low field MR experience. Indian J Med Sci 2006;60:135-42.

10. Bono F, Salvino D, Tallarico T, Cristiano D, Condino F, Fera F, et al. Abnormal pressure waves in headache sufferers with bilateral transverse sinus stenosis. Cephalalgia 2010;30:1419-25. 